\title{
Parasternal Thoracotomy: Review of Twenty-Eight Cases
}

\author{
Massimo Frizzi", Laura Ballarini, Davide Costa, Nicola De Quarto \\ Surgery Department, San Marco Veterinary Clinic, Veggiano, Italy \\ Email address: \\ massimodoc@gmail.com (M. Frizzi) \\ ${ }^{*}$ Corresponding author \\ To cite this article: \\ Massimo Frizzi, Laura Ballarini, Davide Costa, Nicola De Quarto. Parasternal Thoracotomy: Review of Twenty-Eight Cases. Animal and \\ Veterinary Sciences. Vol. 9, No. 4, 2021, pp. 121-127. doi: 10.11648/j.avs.20210904.16
}

Received: August 2, 2021; Accepted: August 16, 2021; Published: August 24, 2021

\begin{abstract}
Pericardiectomy is the preferred surgical procedure for the treatment of pericardial effusions with cardiac tamponade. Surgery is indicated in all cases of recurrent effusions after pericardiocentesis. In the literature, the most frequently used surgical procedure is subtotal pericardiectomy. More recently, minimally invasive techniques have allowed a reduction of morbidity compared to traditional procedures. Aim of this paper is to selectively use the new minimally invasive pericardiectomy technique already described in our previous article and to document the results in a series of twenty-eight cases. Twenty-eight dogs underwent complete blood and urine tests, ultrasound examination, pericardiocentesis and CT scan. In all cases the pericardiectomy was performed via a left parasternal thoracotomy through the seventh intercostal space. All the portions of resected pericardium were measured and histologically examined. All dogs had a neoplastic mass at the base of the heart and no recurrence of the pericardial effusion. All dogs were discharged 24 hours after surgery. Parasternal pericardiectomy may be a good option for the minimally invasive treatment of recurrent pericardial effusions, particularly in the presence of neoplastic lesions of the heart base. The morbidity of the approach is similar to that of other known procedures but it is potentially faster and easier to perform. No dedicated instrumentation is required.
\end{abstract}

Keywords: Pericardial Fenestration, Minimally Invasive Surgery, Parasternal Access

\section{Introduction}

Pericardiectomy is the surgical procedure of choice in the treatment of recurrent cardiac effusions and tamponade unresponsive to medical therapy [1-3]. Several surgical techniques are reported in the literature, the most widely used being subtotal intercostal pericardiectomy throught the fifth right intercostal space or with a sternotomic approach [1-3]. Other less invasive procedures, such as percutaneous pericardiotomy [4], trans-diaphragmatic pericardiectomy [5] and especially thoracoscopic pericardial fenestration [6-11] have allowed a significant reduction of morbidity compared to traditional surgical techniques (in terms of extension of the surgical access, duration of the procedure, post-operative pain, prolonged recovery times). Currently, the minimally invasive thoracoscopic approach is apparently the preferred one, despite the long learning curve and the relatively expensive surgical instrumentation that limit its use and spread in spite of its undoubted usefulness. Aim of this paper is to assess the validity of our new minimally invasive access route to the pericardium in selected patients, comparing it to known procedures through the analysis of the results in twenty-eight clinical cases.

\section{Materials and Methods}

Twenty-eight dogs of different breeds and age (see table 1) were referred to our clinic for relapsing pericardial effusion and cardiac tamponade following treatment with pericardiocentesis. In the previous two weeks all the subjects underwent at least three pericardiocentesis procedures, with an interval ranging from 2 to 5 days. All patients underwent complete blood and urine tests, echocardiographic examination with pericardiocentesis, abdominal ultrasound examination and abdominocentesis; the samples obtained from the pericardial and abdominal effusion underwent chemical-physical examination (PS, PT, total nucleated cells, total red blood cells, $\mathrm{PCV}$, comparison of all biochemical 
parameters with blood values) and cytological examination. After resolution of the acute signs all the dogs underwent a full body CT scan (Siemens-Somaton Definition Flash). Subsequently, a pericardiectomy was performed in all of the patients. A new surgical approach was proposed for this procedure, via a mini-thoracotomy in the left parasternal region. The owners were informed of the unconventional procedure and accepted by signing an informed consent. A careful selection of the patient was performed, based on the following inclusion criteria: A) presence of symptomatic relapsing pericardial effusion; B) need for a minimally invasive approach and for a short duration of the anaesthesia (high anaesthesia risk based on the subject's general conditions, ASA classification and potential risk resulting from iatrogenic pneumothorax caused by thoracoscopic procedures); C) presence of non-resectable neoplastic mass based on the CT examination; D) thoracic exploration and/or pleural biopsies judged unnecessary for the diagnostic approach. All the patients with inflammatory disease pattern or with resectable masses or in which thoracic exploration and/or pleural biopsies were necessary, were not included in this cases series. No patients of the previous six cases series [29] were included in this study. All patients were classified according to the ASA classification. The time required for the entire procedure was recorded from the first incision until closure of the skin suture. All the surgeries were performed by the same surgeon. The protocol for general anaesthesia was as follows: premedication with methadone at the dose of $0.2 \mathrm{mg} / \mathrm{kg}$ and dexmedetomidine at the dose of 1 microgram $/ \mathrm{kg} \mathrm{IV}$; induction with fentanyl at the dose of 2 micrograms $/ \mathrm{kg}$ and propofol at the dose of $3-4 \mathrm{mg} / \mathrm{kg} \mathrm{IV}$; maintenance with endotracheal inhaled isofluorane (1.3\%). In all cases preoperative antibiotic prophylaxis (cefazolin at the dose of $20 \mathrm{mg} / \mathrm{kg} \mathrm{IV}$ ) was performed at the time of induction. The parasternal approach was performed through the seventh left intercostal space, with the patient in dorsal decubitus and with the front limbs extended cranially. Due to the breed variations, it was possible that the incision site varied from the seventh to the eighth intercostal space. However, taking the penultimate sternebra as a reference, it was possible to avoid mistakes. Anyway, a CT processing with volume rendering of the thorax served optimally as a guide to choose the correct space for surgical access. The skin, the subcutaneous tissue and the cutaneous muscle of the trunk were dissected with an incision from the midline (sternum) towards the left side (figure 1). The length of the incision was maintained between 2 and $3 \mathrm{~cm}$, depending on the size of the subject. The rectus abdominis muscle was incised parallel to its fibres, in cranio-caudal direction. The external and internal intercostal muscles and the parietal pleura were incised along the intercostal space. In this anatomical region the two intercostal muscle layers are well separated and therefore clearly distinguishable. Two Gelpi retractors were inserted at $90^{\circ}$ angle (Figure 2). In cases number 18 and 26 a special wound retractor (Surgisleeve wound protector small size-2,5/6 cm. Medtronic/Covidien) was used. The apex of the pericardium, which was always clearly visible in this case series, was identified. Adson forceps were used to exert traction on the pericardium and an incision was made using Metzembaum scissors with bevelled tips (Figure 3). After having established a secure grip of the pericardial tissue by means of Allis forceps an incision was made from the apex in cranial direction, using straight Metzembaum scissors with bevelled tips. The excised portion of the pericardial tissue included the phrenopericardial ligament caudally and the sternopericardial ligament cranially, always ventrally to the phrenic nerves which, in this case series, were always visible, despite the small opening. The procedure was completed by closing the aperture with a routine approach. The intercostal incision was sutured with detached circumcostal polydioxanone stitches (from $2 / 0$ to 0 depending on the size of the subject) while the muscular, fascial and subcutaneous planes were sutured with a continuous resorbable monofilament suture (glycomer 631). The skin incision was closed with a continuous nonabsorbable monofilament suture (polyamide). In all subjects an adhesive skin patch was applied to protect the wound. After surgery, a chest X-ray examination with two views was taken in all of the patients (latero-lateral view in right lateral decubitus and dorsoventral view in sternal decubitus). All the patients were discharged on the same day of surgery or on the next day. At the time of discharge all subjects were assessed with the short form of the Glasgow composite pain scale $[12,28]$ and plasma glucose and cortisol values were assayed [10, 12]. Further assessments were made during the entire hospitalization period, but they were not clinically meaningful since patients underwent analgesic therapy. Follow-up was planned as follows: clinical controls at 7 and 15 days after surgery and then at one, three, six and twelve months after surgery. Blood and urine tests, radiographic examination with two orthogonal views of the chest and ultrasonography of the chest and abdomen were repeated at each follow-up visit. The removed portions of pericardial tissue were measured in their full extension and histologically examined.

Table 1. Summary of clinical cases.

\begin{tabular}{|c|c|c|c|c|c|c|}
\hline Case & Breed and sex & $\begin{array}{l}\text { Age } \\
\text { (years) }\end{array}$ & Ultrasound and $\mathrm{Ct}$ diagnosis & Histopathology (pericardium) & $\begin{array}{l}\text { Histopathology } \\
\text { (tumour) }\end{array}$ & $\begin{array}{l}\text { Survival time } \\
\text { (months) }\end{array}$ \\
\hline 1 & $\begin{array}{l}\text { Sterilized female, } \\
\text { Labrador retriever }\end{array}$ & 11 & Right atrial mass & $\begin{array}{l}\text { Lymphoplasmacellular pericarditis } \\
\text { with medium grade fibrosis }\end{array}$ & $\begin{array}{l}\text { Hemangiosarcoma } \\
\text { of the right atrium }\end{array}$ & 6 \\
\hline 2 & $\begin{array}{l}\text { Sterilized female, } \\
\text { basset hound }\end{array}$ & 12 & $\begin{array}{l}\text { Mass at the base of the heart (suggestive } \\
\text { of chemodectoma of the aortic arch) }\end{array}$ & $\begin{array}{l}\text { Lymphoplasmacellular pericarditis } \\
\text { with medium grade fibrosis }\end{array}$ & Not applicable & 24 \\
\hline 3 & $\begin{array}{l}\text { Intact male, French } \\
\text { bulldog }\end{array}$ & 4 & $\begin{array}{l}\text { Mass at the base of the heart (suggestive } \\
\text { of chemodectoma of the aortic arch) }\end{array}$ & $\begin{array}{l}\text { Lymphoplasmacellular pericarditis } \\
\text { with medium grade fibrosis }\end{array}$ & Not applicable & 48 \\
\hline
\end{tabular}




\begin{tabular}{|c|c|c|c|c|c|c|}
\hline Case & Breed and sex & $\begin{array}{l}\text { Age } \\
\text { (years) }\end{array}$ & Ultrasound and $\mathrm{Ct}$ diagnosis & Histopathology (pericardium) & $\begin{array}{l}\text { Histopathology } \\
\text { (tumour) }\end{array}$ & $\begin{array}{l}\text { Survival time } \\
\text { (months) }\end{array}$ \\
\hline 4 & $\begin{array}{l}\text { Sterilized female } \\
\text { Bernese mountain dog }\end{array}$ & 10 & $\begin{array}{l}\text { Mass at the base of the heart (suggestive } \\
\text { of chemodectoma of the aortic arch) }\end{array}$ & $\begin{array}{l}\text { Lymphoplasmacellular pericarditis } \\
\text { with low grade fibrosis }\end{array}$ & Not applicable & 36 \\
\hline 5 & $\begin{array}{l}\text { Sterilized male, mixed } \\
\text { breed }\end{array}$ & 13 & $\begin{array}{l}\text { Mass at the base of the heart (suggestive } \\
\text { of chemodectoma of the aortic arch) }\end{array}$ & $\begin{array}{l}\text { Lymphoplasmacellular pericarditis } \\
\text { with medium grade fibrosis }\end{array}$ & Not applicable & 24 \\
\hline 6 & Sterilized male Boxer & 13 & $\begin{array}{l}\text { Mass at the base of the heart (suggestive } \\
\text { of chemodectoma of the aortic arch) }\end{array}$ & $\begin{array}{l}\text { Lymphoplasmacellular pericarditis } \\
\text { with medium grade fibrosis }\end{array}$ & Not applicable & 24 \\
\hline 7 & $\begin{array}{l}\text { Sterilized female } \\
\text { mixed breed }\end{array}$ & 11 & Right atrial mass & $\begin{array}{l}\text { Lymphoplasmacellular pericarditis } \\
\text { with medium grade fibrosis }\end{array}$ & $\begin{array}{l}\text { Hemangiosarcoma } \\
\text { of the right atrium }\end{array}$ & 2 \\
\hline 8 & $\begin{array}{l}\text { Sterilized female } \\
\text { mixed breed }\end{array}$ & 11 & Right atrial and ventricular mass & $\begin{array}{l}\text { Lymphoplasmacellular pericarditis } \\
\text { with medium grade fibrosis }\end{array}$ & $\begin{array}{l}\text { Hemangiosarcoma } \\
\text { of the right atrium }\end{array}$ & 1 \\
\hline 9 & $\begin{array}{l}\text { Sterilized female } \\
\text { Golden retriever }\end{array}$ & 11 & Right atrial mass & $\begin{array}{l}\text { Lymphoplasmacellular pericarditis } \\
\text { with medium grade fibrosis }\end{array}$ & Not applicable & 12 \\
\hline 10 & $\begin{array}{l}\text { Sterilized female } \\
\text { medium Poodle }\end{array}$ & 9 & Right atrial mass & $\begin{array}{l}\text { Lymphoplasmacellular pericarditis } \\
\text { with medium grade fibrosis }\end{array}$ & Not applicable & 12 \\
\hline 11 & $\begin{array}{l}\text { Sterilized male cane } \\
\text { Corso }\end{array}$ & 7 & Right atrial mass & $\begin{array}{l}\text { Lymphoplasmacellular pericarditis } \\
\text { with medium grade fibrosis }\end{array}$ & Not applicable & 14 \\
\hline 12 & $\begin{array}{l}\text { Intact male Labrador } \\
\text { retriever }\end{array}$ & 13 & $\begin{array}{l}\text { Mass at the base of the heart (suggestive } \\
\text { of chemodectoma of the aortic arch) }\end{array}$ & $\begin{array}{l}\text { Lymphoplasmacellular pericarditis } \\
\text { with medium grade fibrosis }\end{array}$ & Not applicable & 12 \\
\hline 13 & $\begin{array}{l}\text { Sterilized female } \\
\text { Labrador retriever }\end{array}$ & 11 & Right atrial mass & $\begin{array}{l}\text { Lymphoplasmacellular pericarditis } \\
\text { with medium grade fibrosis }\end{array}$ & Not applicable & 3 \\
\hline 14 & $\begin{array}{l}\text { Sterilized male } \\
\text { Greyhound }\end{array}$ & 8 & Right atrial mass & $\begin{array}{l}\text { Lymphoplasmacellular pericarditis } \\
\text { with low grade fibrosis }\end{array}$ & Not applicable & 8 \\
\hline 15 & $\begin{array}{l}\text { Intact male English } \\
\text { bulldog }\end{array}$ & 10 & $\begin{array}{l}\text { Mass at the base of the heart (suggestive } \\
\text { of chemodectoma of the aortic arch) }\end{array}$ & $\begin{array}{l}\text { Lymphoplasmacellular pericarditis } \\
\text { with medium grade fibrosis }\end{array}$ & Not applicable & 5 \\
\hline 16 & $\begin{array}{l}\text { Sterilized female } \\
\text { Weimaraner }\end{array}$ & 4 & $\begin{array}{l}\text { Mass at the base of the heart (suggestive } \\
\text { of chemodectoma of the aortic arch) }\end{array}$ & $\begin{array}{l}\text { Lymphoplasmacellular pericarditis } \\
\text { with medium grade fibrosis }\end{array}$ & Not applicable & 7 \\
\hline 17 & Intact male Beagle & 8 & Right atrial mass & $\begin{array}{l}\text { Lymphoplasmacellular pericarditis } \\
\text { with medium grade fibrosis }\end{array}$ & Not applicable & 6 \\
\hline 18 & $\begin{array}{l}\text { Sterilized female } \\
\text { Labrador retriever }\end{array}$ & 9 & Pericardial mass & $\begin{array}{l}\text { Lymphoplasmacellular pericarditis } \\
\text { with medium grade fibrosis }\end{array}$ & Not applicable & 12 \\
\hline 19 & $\begin{array}{l}\text { Sterilized male } \\
\text { French bulldog }\end{array}$ & 10 & $\begin{array}{l}\text { Mass at the base of the heart (suggestive } \\
\text { of chemodectoma of the aortic arch) }\end{array}$ & $\begin{array}{l}\text { Lymphoplasmacellular pericarditis } \\
\text { with medium grade fibrosis }\end{array}$ & Not applicable & 24 \\
\hline 20 & $\begin{array}{l}\text { Sterilized male } \\
\text { English bulldog }\end{array}$ & 9 & $\begin{array}{l}\text { Mass at the base of the heart (suggestive } \\
\text { of chemodectoma of the aortic arch) }\end{array}$ & $\begin{array}{l}\text { Lymphoplasmacellular pericarditis } \\
\text { with medium grade fibrosis }\end{array}$ & Not applicable & 36 \\
\hline 21 & $\begin{array}{l}\text { Sterilized male } \\
\text { Labrador retriever }\end{array}$ & 10 & $\begin{array}{l}\text { Mass at the base of the heart (suggestive } \\
\text { of chemodectoma of the aortic arch) }\end{array}$ & $\begin{array}{l}\text { Lymphoplasmacellular pericarditis } \\
\text { with medium grade fibrosis }\end{array}$ & Not applicable & 24 \\
\hline 22 & $\begin{array}{l}\text { Sterilized female } \\
\text { French bulldog }\end{array}$ & 9 & $\begin{array}{l}\text { Mass at the base of the heart (suggestive } \\
\text { of chemodectoma of the aortic arch) }\end{array}$ & $\begin{array}{l}\text { Lymphoplasmacellular pericarditis } \\
\text { with low grade fibrosis }\end{array}$ & Not applicable & 24 \\
\hline 23 & $\begin{array}{l}\text { Sterilized female } \\
\text { Bernese mountain dog }\end{array}$ & 10 & $\begin{array}{l}\text { Mass at the base of the heart (suggestive } \\
\text { of chemodectoma of the aortic arch) }\end{array}$ & $\begin{array}{l}\text { Lymphoplasmacellular pericarditis } \\
\text { with medium grade fibrosis }\end{array}$ & Not applicable & 12 \\
\hline 24 & Sterilized male Boxer & 8 & $\begin{array}{l}\text { Mass at the base of the heart (suggestive } \\
\text { of chemodectoma of the aortic arch) }\end{array}$ & $\begin{array}{l}\text { Lymphoplasmacellular pericarditis } \\
\text { with medium grade fibrosis }\end{array}$ & Not applicable & 48 \\
\hline 25 & $\begin{array}{l}\text { Intact male mixed } \\
\text { breed }\end{array}$ & 10 & $\begin{array}{l}\text { Mass at the base of the heart (suggestive } \\
\text { of chemodectoma of the aortic arch) }\end{array}$ & $\begin{array}{l}\text { Lymphoplasmacellular pericarditis } \\
\text { with medium grade fibrosis }\end{array}$ & Not applicable & 24 \\
\hline 26 & $\begin{array}{l}\text { Sterilized male } \\
\text { German Sheperd }\end{array}$ & 12 & Right atrial mass & $\begin{array}{l}\text { Lymphoplasmacellular pericarditis } \\
\text { with medium grade fibrosis }\end{array}$ & Not applicable & 6 \\
\hline 27 & $\begin{array}{l}\text { Intact male English } \\
\text { Coker Spaniel }\end{array}$ & 15 & Left ventricular mass & $\begin{array}{l}\text { Lymphoplasmacellular pericarditis } \\
\text { with low grade fibrosis }\end{array}$ & Not applicable & 5 \\
\hline 28 & $\begin{array}{l}\text { Sterilized female } \\
\text { Cane Corso }\end{array}$ & 10 & Right atrial mass & $\begin{array}{l}\text { Lymphoplasmacellular pericarditis } \\
\text { with medium grade fibrosis }\end{array}$ & $\begin{array}{l}\text { Hemangiosarcoma } \\
\text { of the right atrium }\end{array}$ & 2 \\
\hline
\end{tabular}

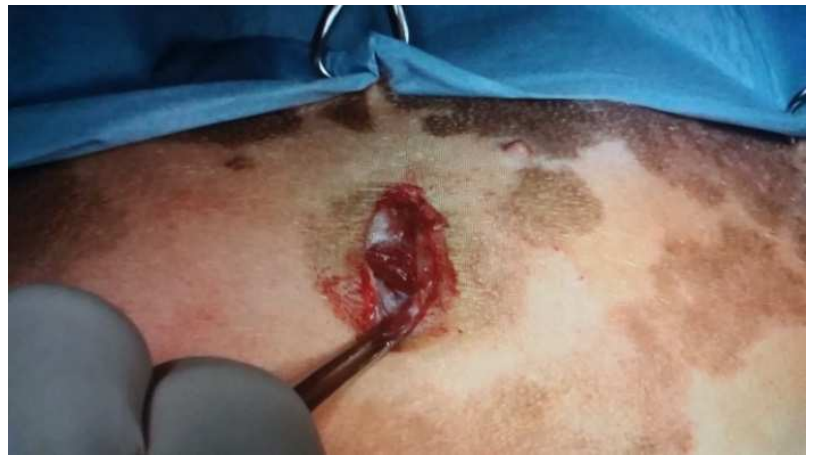

Figure 1. Skin incision.

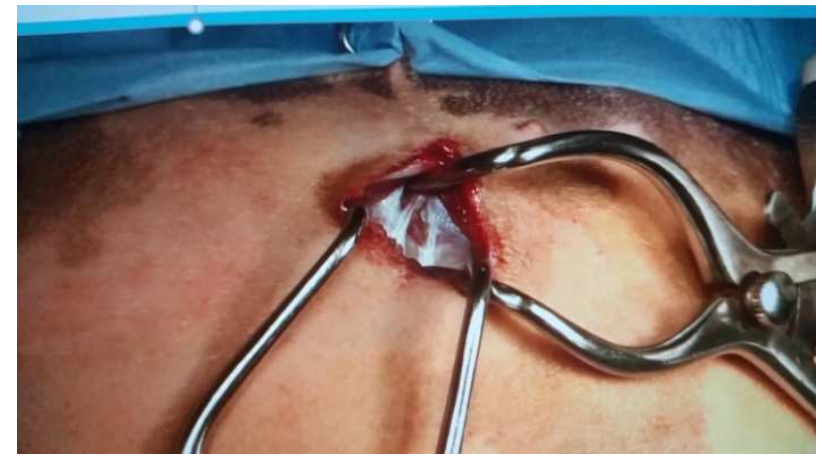

Figure $2.90^{\circ}$ degree positioning of Gelpi retractors. 


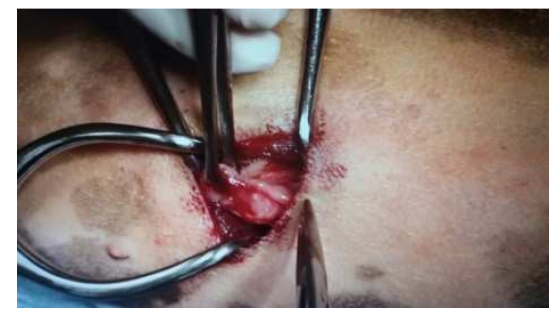

Figure 3. Traction and incision of the pericardium.

\section{Results}

In all of the subjects the symptoms present were weakness, abdominal distension, respiratory distress, weak and thin pulse, weakened heart noises at chest auscultation. Abdominal distension was, in all cases, caused by ascites due to decreased venous return consequent to the pericardial effusion. All patients were classified as ASA 3 or 4 . In the pericardial effusions the protein concentration was always higher than $3 \mathrm{gr} / \mathrm{dl}$, while the cell count was variable between 2200 to 7000 cells $/ \mu 1$, with a mixed population of mesothelial/inflammatory cells. A slight prevalence of neutrophils over other cell types was found in five cases. In the peritoneal effusions the protein concentration always remained in a range between 2.5 to $3.5 \mathrm{gr} / \mathrm{dl}$; in all cases the cell count was below 1000 cells/ $\mu$. In all the patients, in addition to pericardial and abdominal effusion ultrasonography detected the presence of a mass at the base of the heart. In compliance with the ultrasound results, in all the cases CT confirmed the presence of a mass at the base of the heart. CT scans also allowed a more specific characterisation of the type of neoplasm present: in twelve cases the diagnostic suspicion was of haemangiosarcoma of the right atrium; in fifteen cases the findings were suggestive of a chemodectoma originating from the aortic arch (Figure $4)$; in one case the images suggested the presence of a primary neoplasm of the pericardium. In all cases no other pathological findings were encountered, other than the abdominal effusion. In one case there was bleeding from the internal thoracic artery, controlled by cauterization with electrosurgical units. In no other case intraoperative complications occurred. Only one patient had pneumothorax after surgery, resolved with a single thoracentesis. In five cases there was a mild ventral pneumomediastinum, which did not require any treatment (Figure 5). In all the other subjects no signs of pneumothorax or pneumomediastinum were present at the post-operative radiographic examination. Hospitalization time varied between 10 and 24 hours. In one case there was dehiscence of the skin wound, which require revision surgery with subsequent healing. In all the other cases the surgical wounds healed without complications. The mean duration of surgery was of 22 minutes and 10 seconds (range from 19 to 25 minutes). The Glasgow pain score at the time of discharge was in all subjects between 2 and 5 (range 0-24); plasma glucose and cortisol concentrations were normal (glucose: mean 110, minimum 98, maximum 120, reference interval $90-120 \mathrm{mg} / \mathrm{dl}$; cortisol: mean 7.50 , minimum 2.30, maximum 12.40 , reference interval 1.10-13.3 $\mu \mathrm{g} / \mathrm{dl})$. Recurrence of the pericardial effusion was absent in all the dogs. All the removed portions of the pericardium were measured in their full extension. The mean surface area of the resected pericardial membrane was of $28.50 \mathrm{~cm}^{2}$ (15 to $\left.48 \mathrm{~cm}^{2}\right)$. All the removed portions of pericardium were histologically examined. In all the subjects the histological diagnosis was of lymphoplasmacellar pericarditis with low/medium grade fibrosis. The mean age of disease presentation was 9.93 years (range 4 to 15), with the majority of subjects 8-13 years old. The mean weight of the patients was $21.5 \mathrm{~kg}$ (range 7 to $45 \mathrm{~kg}$ ) with the majority of subjects weighing more than $15 \mathrm{~kg}$. The average survival time of subjects with suspected haemangiosarcoma was 6.5 months (range 1-14 months) while that of subjects with suspected chemodectoma was 2 years and 8 months (range 5 months- 4 years). In three of the nine cases with hemangiosarcoma the death is certainly due to sudden rupture of the mass with acute bleeding (post mortem necropsy).

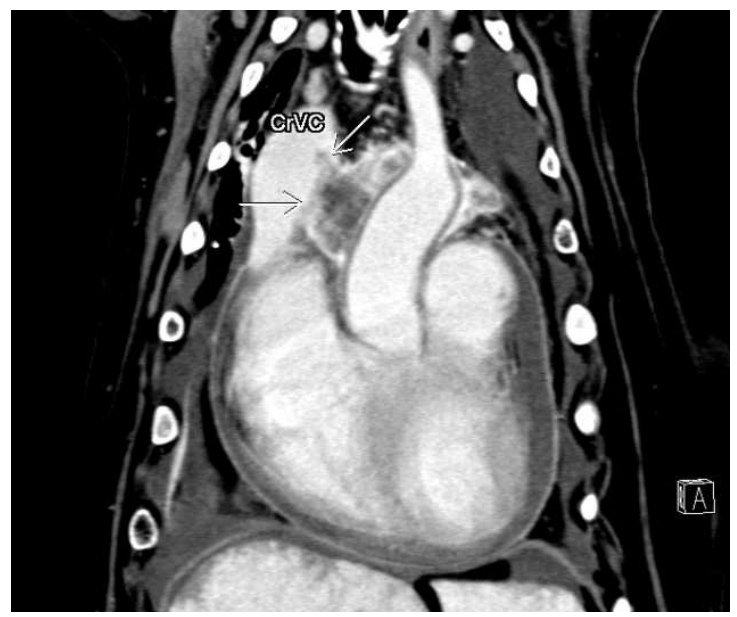

Figure 4. CT coronal scan-chemodectoma with invasion of the cava vein.

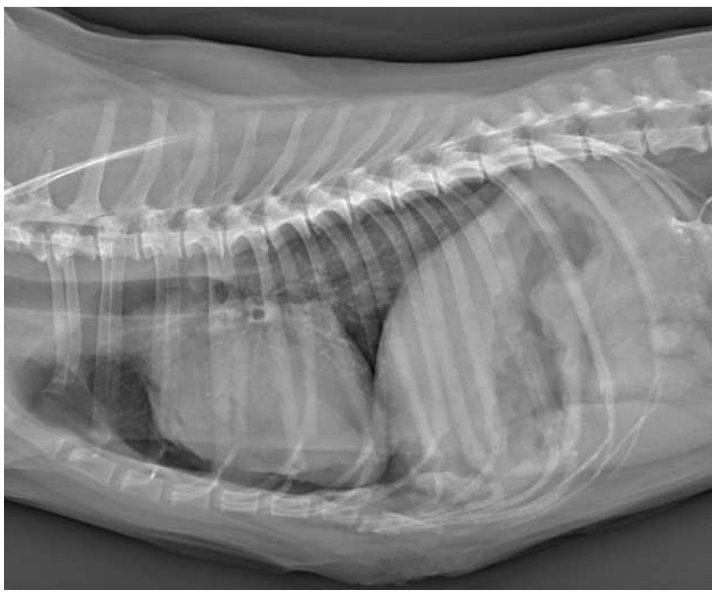

Figure 5. Post. op. ventral pneumomediastinum.

\section{Discussion}

The mean duration of this new surgical procedure resulted to be lower compared to what reported in the literature for the more invasive open surgery procedures and for 
thoracoscopic fenestration [1-11]. No specific instrumentation was required. The execution of the procedure by a single surgeon may be a limitation of the study, as the results may have been influenced by the experience of the surgeon who ideated the procedure and hence may have not shown the real difficulties of the technique. Hospitalization time and postoperative pain were comparable to those observed with thoracoscopic procedures, both in our experience and if compared to what reported in the literature $[6-12,14]$. The short form of the Glasgow composite pain scale and blood concentrations of glucose and cortisol were selected as criteria for the assessment of post-operative pain in accordance with what reported in the literature $[10,12,14$, 28]. At the time of the last evaluation, on discharging, none of the subjects were under treatment with analgesics. In none of the cases the pre-operative antibiotic prophylaxis was continued in the post-operative period. These last two observations may support the impression of a low morbidity of the procedure. In none of the patients treated a thoracic drainage was used. Although the use of pleural drainage after thoracic surgery is recommended in the literature, based on our previous experience with pericardiectomy - both with this technique and with other minimally invasive techniques not included in this case series - the decision was taken to standardize the surgery with a minimally invasive approach, without applying thoracic drainage. This may have had a significant impact on both the short duration of hospitalization and on the extent of post-surgical pain giving the impression that the low morbidity is due solely to the procedure itself.. In only one case pneumothorax was detected. This was probably due to the surgeon's ability in not damaging the visceral pleurae lining the lungs during dissection of the pericardium but also due to the shortness of the surgery and to the small size of the surgical approach that allows a small amount of ambient air to enter the chest. The absence of complications during the procedures (apart one case of bleeding from internal thoracic artery) is probably related to the small number of cases and should therefore be considered with caution. Potential complications could include bleeding of intercostal blood vessels, of the epicardium and of the coronary vessels, pneumothorax in case of extensive dissection of the ventral mediastinum, iatrogenic damage to the phrenic nerves, seroma/ haematoma and infection of the surgical wound. In our study, the survival time of patients with neoplastic disease was comparable to the one reported in the literature for the same type of cancer (particularly long in the case of chemodectoma) [15, 17-21, 25-26, 30-31]. In 50\% of suspected chemodectoma cases, subjects were boxers, French or English bulldogs, suggesting a predisposition for this neoplasm in brachycephalic breeds, according to the literature $[15,16]$. In this cases series the pericardial effusion relapse rate was zero, supporting the hypothesis that in such cases this procedure can be used advantageously. According to the data available in the literature, the mean surface area of pericardium removed was higher compared to other fenestration techniques [6-10, 12], lower compared to more invasive open surgical techniques [1-
$3,24]$ and similar to the one observed with transdiaphragmatic pericardiectomy [5]. As the study was not performed ex-vivo, it was not possible to evaluate the percentage of pericardium removed; however, in three deceased subjects (haemangiosarcoma rupture) necropsy allowed a subjective evaluation of this percentage as being of approximately $40 \%$ (a value comparable to what found in the literature for transdiaphragmatic pericardiectomy) [5]. The absence of recurrence, despite the long follow-up of many cases, suggests that the fenestration is large enough to prevent adherence to the epicardium or to the fibrous and mediastinal tissue, that is a reported complication with other fenestration techniques [10, $13,34]$. Finally, in our series we did not find any cases of cardiac herniation/entrapment through the pericardial window, that is another reported complication in the human and veterinary literature [10]. These observations support the hypothesis of the size adequacy of the pericardiectomy.

\section{Conclusion}

In the authors' opinion parasternal intercostal pericardiectomy can be considered a valid alternative to thoracoscopic fenestration procedures in the treatment of symptomatic and relapsing pericardial effusions, particularly when caused by neoplastic disease at the base of the heart. Being a minimally invasive technique, similarly to thoracoscopic fenestration, in the presence of occasional masses at the base of the heart that have not yet caused a tamponade, the procedure may be also considered as a preventive surgical intervention. This access route can also be used for a pericardial biopsy when this is the only indication, as in cases of diffuse infiltrative disease of the pericardium (for example pericarditis, suspected lymphoma o mesothelioma) [22-23, 27, 32-34]. The technique is potentially fast and easy to learn and execute; it presents low risks of complications and does not require dedicated instrumentation. A careful selection of the patient is advisable, based on the previous reported inclusion criteria. The limited number of patients in our study makes further investigations appropriate, especially for the evaluation of complications (e.g., comparison between parasternal thoracotomy and thoracoscopic fenestration in control groups without prior patient selection, execution of the procedure by different surgeons).

\section{Acknowledgements}

We thank all the members of the Anaesthesia and PostOperative Care Unit of the San Marco Veterinary Clinic for their support and for how they took care of our patients.

\section{References}

[1] Michael G, Aronsohn, JL, Carpenter Surgical treatment of idiopathic pericardial effusion in the dog: 25 cases (19781993). Journal of the American Animal Hospital Association 35: 521-525, 1999. 
[2] Kyle K, Kerstetter, DJ, Krahwinkel JR Darryl L, Millis et al. Pericardiectomy in dogs: 22 cases (1978-1994). Journal of the American Veterinary Medical Association, September 15, volume 211, $\mathrm{n}^{\circ}$ 6: 736-740, 1997.

[3] Shaw SP, Rush JE Canine pericardial effusion: diagnosis, treatment and prognosis. CompendiumVet.com, July: 405-411, 2007. URL: Canine Pericardial Effusion. Available at: http://www.researchgate.net/publication/6113442_Canine_peri cardial_effusion.

[4] Sidley JA, Atkins CE, Keene BW et al. Percutaneous Balloon Pericardiotomy as a treatment for recurrent pericardial effusion in 6 dogs. Journal of Veterinary Internal Medicine 16: 541-546, 2002.

[5] De Ridder M, Kitshoff A, Devriendt $\mathrm{N}$ et al. Transdiaphragmatic pericardiectomy in dogs. Veterinary Record (Official Journal of British Veterinary Association) volume 180, $\mathrm{n}^{\circ}$ 4: 1-6, 2016. URL: Transdiaphragmatic pericardiectomy. Available at: http://www.veterinaryrecord.bmj.com/content/180/4/95 or doi: $10.1136 /$ vr.103962

[6] Jackson J, Richter KP and Launer DP Thoracoscopic partial pericardiectomy in 13 dogs. Journal of Veterinary Internal Medicine, 13: 529- 533, 1999.

[7] Atencia S, Doyle RS and Whitley NT Thoracoscopic pericardial window for management of pericardial effusion in 15 dogs. Journal of Small Animal Practice, November 54: 564-569, 2013.

[8] Dupre' GP, Corlouer JP, Bouvy B Thoracoscopic pericardiectomy performed without pulmonary exclusion in 9 dogs. Veterinary Surgery, 30: 21-27, 2001.

[9] Abarkar M, Sharifi D, Kariman A et al. Evaluation of intraoperative complications in pericardiectomy with transdiaphragmatic thoracoscopic approach in dog. Iranian Journal of Veterinary Surgery, volume 2, $n^{\circ}$ 4: 62-68, 2007.

[10] Laura A. Barbur Clarence A. Rawlings MaryAnn G. Radlinsky Epicardial exposure provided by a novel thoracoscopic pericardectomy technique compared to standard pericardial window Veterinary Surgery.

[11] Chad Schmiedt What is the optimal approach for pericardiectomy in dogs? Veterinary Record | January 28, 2017.

[12] Case JB, Maxwell M, Aman A et al. Outcome evaluation of thoracoscopic pericardial window procedure or subtotal pericardiectomy via thoracotomy for treatment of pericardial effusion in dogs. Journal of American Veterinary Medical Association, February 15, volume 242, $\mathrm{n}^{\circ}$ 4: 493-498, 2013.

[13] Nguyen Thanh Liem, To Tuan and Le Anh Dung, Thoracoscopic pericardiectomy for purulent pericarditis: experience with 21 cases. Journal of Laparoendoscopic \& Advanced Surgical Techniques, volume 16, $\mathrm{n}^{\circ}$ 5: 518-521, 2006.

[14] Walsh PJ, Remedios AM, Ferguson JF et al. Thoracoscopic versus open partial pericardiectomy in dogs: comparison of postoperative pain and morbidity. Veterinary Surgery, 28: 472479, 1999.

[15] Vicari ED, Brown DC, Holt DE et al. Survivor times of and prognostic indicators for dogs with heart base masses: 25 cases (1986-1999). Journal of American Veterinary Medical
Association, August 15, volume 219, $\mathrm{n}^{\circ}$ 4: 485-487, 2001.

[16] Ehrhart N, Ehrhart J, Willis J et al. Analysis of factor affecting survival in dogs with aortic body tumours. Veterinary Surgery 31: 44-48, 2002.

[17] Weisse C, Soares N, Beal MW et al. Survival times in dogs with right atrial hemangiosarcoma treated by means of surgical resection with or without adjuvant chemotherapy: 23 cases (1986-2000). Journal of American Veterinary Medical Association, February 15, volume 226, n 4: 575-579, 2005.

[18] Aronsohn M. Cardiac hemangiosarcoma in the dog: a review of 38 cases. Journal of American Animal Hospital Association, 187: 922-926, 1985.

[19] P T. Gunasekaran, N. B. Olivier, Smedley, R. A. Sanders, Pericardial Effusion in a Dog with Pericardial Hemangiosarcoma Journal of Veterinary Cardiology (2019) $23,81 \mathrm{e} 87$.

[20] M. DeSandre-Robinson, Mariana T. Quina, David M. Lurie, Pericardial Hemangiosarcoma in a 10-Year-Old Papillon Journal of the American Animal Hospital Association | 54: 5 Sep/Oct 2018.

[21] T Denise M. Crumbaker, Matthew B. Rooney, J. Brad Case, Thoracoscopic subtotal pericardiectomy and right atrial mass resection in a dog Journal of the American Veterinary Medical Association, Vol 237, No. 5, September 1, 2010.

[22] Hellen Fialho HARTMANN, Marília Teresa de OLIVEIRA, João Pedro Scussel FERANTI, Gabriela Pesamosca CORADINI, Stephanie Lanzarini ABATI, Bibiana Zoppas PIEREZAN, Vanessa Zanchi SARTURI, Marcella Teixeira LINHARES, Álvaro José Chávez SILVA Francisco Miguel Sanchez MARGALLO, Anne Santos do AMARAL and Maurício Veloso BRUN Thoracoscopic pericardiectomy associated with fully implantable catheter via thoracoscopy 5 in the management of mesothelioma in a bitch Journal of Veterinary Medical Science. April 2019.

[23] Keaton R. S. Morgan, Christopher G. Dominic, Janet BeelerMarfisi, Karlee Craig, Katie L. Hoddinott, Siobhan O'Sullivan, Ameet Singh Presumptive seeding metastasis of pericardial mesothelioma following repeated pericardiocentesis in a dog Canadian Veterinary Journal 2019; 60: 972-975.

[24] Skinner OT, Case JB, Ellison GW et al. Pericardioscopic imaging findings in cadaveric dogs: comparison of an apical pericardial window and sub-phrenic pericardiectomy. Veterinary Surgery, 43: 45-51, 2014.

[25] Johnson MS, Martin M, Binns S et al. A retrospective study of clinical findings, treatment and outcome in 143 dogs with pericardial effusion. Journal of Small Animal Practice, 45: 546-552, 2004.

[26] Stray-Gundersen J, Musch TI, Haidet GC et al. The effect of pericardiectomy on maximal oxygen consumption and maximal cardiac output in untrained dogs. Circulation Research, Journal of the American Heart Association, January 23, 523-530, 2017.

[27] Chan A, Rischin D, Clarke CP et al. Subxiphoid partial pericardiectomy with or without sclerosant instillation in the treatment of symptomatic pericardial effusion in patients with malignancy. Cancer, September 1, volume 68: 1021-1025, 1991. 
[28] Jacky R, Nolan AM, Lynne HJM et al. Development of the short-form Glasgow Composite Measure Pain Scale (CMPS$\mathrm{SF}$ ) and derivation of an analgesic intervention score. Animal Welfare, volume 16, Supplement 1, May: 97-104 (8), 2007.

[29] Frizzi M, D’Ettorre P, Bertolini G, Angeloni L, Parasternal thoracotomy: a new minimally invasive approach to the pericardium. Veterinaria, February, vol 32, issue 1, 2018.

[30] Simon Cook Stefano Cortellini Karen Humm Retrospective evaluation of pericardial catheter placement in the management of pericardial effusion in dogs (2007-2015): 18 cases Journal of Veterinary Emergency and Critical Care. 2019; 1-5.

[31] Simon Cook Stefano Cortellini Karen Humm Prospective evaluation of pericardial catheter placement versus needle pericardiocentesis in the management of canine pericardial effusion Journal of Veterinary Emergency and Critical Care. $2020 ; 1-7$.
[32] Jose L. Carvajal J. Brad Case | Philipp D. Mayhew | Jeffrey Runge Ameet Singh Sarah Townsend | Eric Monnet Outcome in dogs with presumptive idiopathic pericardial effusion after thoracoscopic pericardectomy and pericardioscopy Veterinary Surgery. $2018 ; 1-7$.

[33] Terence A. Krentz Robert J. Schutrumpf Julie C. Zitz, Focal intramural pericardial effusion and cardiac tamponade associated with necrotic adipose tissue in a dog Journal of the American Veterinary Medical Association Vol 251 No. 2 July 15, 2017.

[34] Kurt P. Michelotti Ada Youk John T. Payne Jonathan Anderson Outcomes of dogs with recurrent idiopathic pericardial effusion treated with a 3-port right-sided thoracoscopic subtotal pericardiectomy Veterinary Surgery 2019, 1-10. 